\title{
Effect of Biofumigation with Plant Extracts on Mycelial Growth and Sclerotial Germination of Rhizoctonia solani Causing Collar Rot and Web Blight of Cowpea
}

\author{
K.P. Aparna* and V.K. Girija \\ Department of Plant Pathology, College of Agriculture, Vellayani, \\ Thiruvananthapuram, India \\ *Corresponding author
}

\begin{abstract}
A B S T R A C T
Plants synthesize secondary metabolites and some of them as well as their derivatives have antimicrobial activity such as alkaloids, flavonoids, isoflavonoids, tannins, coumarins, glucosides, terpenes and phenolic compounds. An attempt was made to evaluate the in vitro antifungal and biofumigant nature of ten different plants on suppression of mycelial

\begin{tabular}{|c|}
\hline Keywords \\
\hline $\begin{array}{l}\text { Rhizoctonia solani, } \\
\text { Biofumigation, } \\
\text { Antifungal nature, } \\
\text { Mycelial regeneration } \\
\text { from sclerotia }\end{array}$ \\
\hline Article Info \\
\hline $\begin{array}{l}\text { Accepted: } \\
24 \text { February } 2018 \\
\text { Available Online } \\
10 \text { March } 2018\end{array}$ \\
\hline
\end{tabular}
growth of $R$. solani. Among these plant extracts at a concentration of $12.5 \%$, total inhibition of the pathogen was obtained on PDA incorporated with leaf extracts of cabbage and garlic creeper. The extracts of leaves of sweet potato (37.44\%) and radish (30.00\%) also gave significant suppression. Under in vitro evaluation of the biofumigant nature of plants, complete suppression of the pathogen was obtained on treatment with cabbage, cassava, garlic creeper and mustard. This was followed by radish, moringa, neem and lemon grass which gave suppression of $87.80 \%, 83.30 \%, 77.80 \%$ and $76.67 \%$, respectively. Among the plants, cabbage, garlic creeper and mustard were found to be very effective biofumigants and caused $100 \%$ suppression on mycelial regeneration from sclerotia $24 \mathrm{~h}$ after exposure to the treatment. After a period of two weeks of biofumigation with cassava $100 \%$ suppression on sclerotial growth was noticed. Biofumigation with leaves of other plants such as sweet potato, moringa, papaya, neem and lemongrass, which are widely grown in the state afforded suppression of $81.85,81.11$, $79.63,77.04$ and $76.67 \%$, respectively one month after exposure to the treatment. In general, biofumigation with plants exerted suppression of mycelial regeneration from sclerotia. The extent of suppression was found to increase with increase in period of incubation with biofumigants.
\end{abstract}

\section{Introduction}

Cowpea [Vigna unguiculata (L.) Walp] is remunerative crop grown for its immature pods used as vegetable. Cowpea is susceptible to an array of pathogens which can result in substantial loss in yield. Among the fungal diseases collar rot caused by Rhizoctonia solani is a major concern. $R$. solani survives in soil as sclerotia which are compressed mycelia that enable it to persist in soil for long periods in the absence of host plant (Upamanyu et al., 2002). The primary spread of infection starts from sclerotia. The perfect stage of the 
pathogen is a basidiomycete fungus that never formed conidia and produced only basidiospores (Agrios, 1997). The hyphae and sclerotia were produced by the imperfect stage, $R$. solani, whereas, basidiospores were formed by the perfect stage in soil (Tiwari and Khare, 2002). The longevity of sclerotia is variable, and influenced by many factors including the time and depth of burial and soil type (Duncan et al., 2006). Under favourable conditions a large proportion of sclerotia can survive at least 3 years in the soil (Cosic et al., 2012).

Considering the soil borne nature, survival mechanisms and wide host range, the management of the disease is difficult, though possible through several cultural, biological or chemical means (Sindhan et al., 1999; Rodrigues et al., 2001; Kumar et al., 2014; Patel et al., 2014; KAU, 2016). However, as with all endemic soilborne pathogens, attempts to reduce the soil inoculum reserves through crop rotation, soil solarisation or soil fumigation have been found to offer better results. The former two methods are time consuming, whereas, the latter involves the use of hazardous chemicals. As an ecofriendly alternative to the latter, biofumigation using plants or products derived from them could be tested for their usefulness for soilborne pathogen eradication.

Soil biofumigation is an emerging ecofriendly strategy for reducing the soilborne plant pathogens such as $R$. solani. The research in this direction has gained momentum with the ban imposed on the use of methyl bromide and other chemical fumigants owing to the damage caused through ozone depletion and carcinogenic effects (Prasad et al., 2016). The term biofumigation was originally coined by Kirkegaard in 1993. Biofumigation is the process of growing, macerating / incorporating certain Brassica or related species into the soil leading to the release of the endogenous enzyme, myrosinase that hydrolyzed glucosinolates (GSLs) to isothiocyanate compounds (ITCs) (Kirkegaard et al., 1993). Sarwar et al., (1998) suggested that propenyl ITC and 2-phenyl-ethyl ITC, from Brassica sp. suppressed soilborne pathogens such as $R$. solani, $F$. graminearum, and Gueaumanomyces graminis tritici. Matthiessen and Kirkegaard (2006) reported that the volatile principle, ITCs in Brassica sp. resembled methyl isothiocyanate, the active component of several chemical fumigants, and therefore, they were identified to be suitable alternatives to chemical fumigants. Redovnikovic et al., (2008) detailed GSLs as secondary metabolites with sulphur and nitrogen groups.

\section{Materials and Methods}

Cowpea plants showing typical collar rot symptom were collected from the Instructional Farm of College of Agriculture, Vellayani, Thiruvananthapuram, Kerala state during Kharif 2016. The infected portions were first washed in running water and cut into small bits, surface sterilized with $0.1 \%$ mercuric chloride $\left(\mathrm{HgCl}_{2}\right)$ solution for one $\mathrm{min}$. followed by two successive washings in sterile water, and then transferred into sterile petriplates containing potato dextrose agar (PDA) medium under aseptic conditions. These petri plates were sealed with parafilm and incubated at room temperature $\left(28 \pm 1^{\circ} \mathrm{C}\right)$ for the development of fungal growth. The culture thus obtained was purified by hyphal tip method on PDA slants. The pathogenicity tests were performed and the causal agent was identified based on morphological and cultural characteristics. The antifungal nature of different plant tissues against $R$. solani was tested by poisoned food technique (Nene and Thapliyal, 1993). One hundred gram fresh leaf tissues of eleven different plants [viz. cabbage (Brassica oleracea var. capitata L.), cassava (Manihot esculenta Crantz), garlic creeper 
(Mansoa alliacea Lam.), lemon grass (Cymbopogon flexuosus [Nee ex Steudel] J.F. Watson), moringa (Moringa oleifera Lam.), mustard (Brassica juncea L.), neem (Azadirachta indica A. Juss.), papaya (Carica papaya Linn.), radish (Raphanus sativus L.), sweet potato (Ipomoea batatas (L.) Lam.)] known to contain biocidal compounds were collected, washed and drained to remove excess water. The extracts were prepared as per Paul and Sharma (2002). These plants were ground in $100 \mathrm{ml}$ of sterile water, filtered through muslin cloth and filtrate obtained was centrifuged at $6000 \mathrm{rpm}$ for $25 \mathrm{~min}$. The supernatant filtered through Whatman no. 42 filter paper was collected in screw capped bottle, and $2.5 \mathrm{ml}$ of each of the concentrated leaf extract was diluted with $7.5 \mathrm{ml}$ sterile water and finally $10 \mathrm{ml}$ diluted volume of leaf extract was added to equal volume of sterilized double strength PDA medium taken in conical flask and the amended medium was poured into petri plates to get a concentration of $12.5 \%$ of the plant extract. $5 \mathrm{~mm}$ diameter mycelial disc was taken from 7 day old culture of R.solani and placed at the centre of petriplate. The un-amended PDA medium inoculated with pathogen served as the control. The inoculated plates were incubated at $28 \pm 11^{\circ} \mathrm{C}$. Observation on colony diameter was recorded when the control plates were fully covered by $R$. solani. Percentage inhibition in colony growth was recorded as per Vincent (1947).

Biofumigant nature of test plants was determined by the method of Charron and Sams (1999). Leaves of test plants were macerated using mortar and pestle. Bases of two equal sized sterilized Petri plates were taken. $2.5 \mathrm{~g}$ of the macerated tissue was placed at the centre of the one kept at the bottom. The sterile molten PDA was poured into other lid and this was inoculated with $5 \mathrm{~mm}$ mycelial disc cut from 7 day old $R$. solani culture grown on PDA and was inverted over the other plate containing the macerated plant tissue. The adjoining portions of two petriplates were sealed with parafilm. The paired plates with upper inverted plate carrying PDA and inoculated pathogen alone at the basal plate served as control. Percentage suppression of the pathogen over control was calculated as already mentioned. The effect of biofumigation on mycelial regeneration from sclerotia was tested in confined containers under in vitro with those plants described already (50 $\mathrm{g} \mathrm{kg}^{-1}$ soil). The methodology was given by Dhingra et al., (2013). Garden soil was collected in polypropylene covers and sterilized at $1.02 \mathrm{~kg} \mathrm{~cm}^{-2}$ for $1 \mathrm{~h}$ (Plate 1a). Sclerotia were taken from seven day old cultures of $R$. solani and kept in sterilized muslin cloth bags at the rate three per bag under aseptic conditions (Plate 1b). The plastic container of capacity $1 \mathrm{~L}$ was selected and its half portion was filled with sterilized garden soil. Biofumigant such as macerated fresh plant tissue (50 $\mathrm{g} \mathrm{kg}^{-1}$ soil)/ plant oil (5\% soil drench)/ oil cake (10 $\mathrm{g} \mathrm{kg}^{-1}$ soil) was incorporated into the soil filled in plastic container and over that after sprinkling sterile water another layer of sterilized garden soil was given. Four muslin cloth bags were added per container and plastic container was closed with its lid (Plate 1c). The effect of volatiles from biofumigants on mycelial re-generation from sclerotia was assessed by inoculating treated sclerotia on PDA at intervals of $24 \mathrm{~h}$, one week, two weeks and one month. The confined container with inoculum and without biofumigant served as control. The percentage suppression of the pathogen over control was calculated using the formula described by Vincent (1947).

\section{Results and Discussion}

The results (Table 1) indicated that the extracts of the different plants showed significant differences in suppression of $R$. solani. 
Table.1 Effect of antifungal nature of plants on $R$. solani under in vitro conditions

\begin{tabular}{|l|l|l|}
\hline Plants & Mycelial growth* $(\mathrm{cm})$ & \% Inhibition \\
\hline P1 (Cabbage) & 0.00 & $100.00^{\mathrm{a}}(89.04)$ \\
\hline P2 (Cassava) & 9.00 & $0.00^{\mathrm{e}}(0.96)$ \\
\hline P3 (Garlic creeper) & 0.00 & $100.00^{\mathrm{a}}(89.04)$ \\
\hline P4 (Lemongrass) & 9.00 & $0.00^{\mathrm{e}}(0.96)$ \\
\hline P5 (Moringa) & 9.00 & $0.00^{\mathrm{e}}(0.96)$ \\
\hline P6 (Mustard) & 8.53 & $5.22^{\mathrm{d}}(13.07)$ \\
\hline P7 (Neem) & 7.50 & $16.67^{\mathrm{c}}(24.09)$ \\
\hline P8 (Papaya) & 9.00 & $0.00^{\mathrm{e}}(0.96)$ \\
\hline P9 (Radish) & 6.30 & $30.00^{\mathrm{b}}(32.97)$ \\
\hline P10 (Sweet potato) & 5.63 & $37.44^{\mathrm{b}}(39.80)$ \\
\hline Control & 9.00 & - \\
\hline SE m $( \pm)$ & - & 0.24 \\
\hline CD $(0.05)$ & - & 0.73 \\
\hline
\end{tabular}

(Figures given in the parenthesis are transformed values).

*Mean of three replications. Means followed by a common letter(s) are not significantly different by one- way ANOVA at $\mathrm{P}=0.05$ )

Table.2 Biofumigant effect of plants on $R$. solani under in vitro conditions

\begin{tabular}{|l|c|c|}
\hline \multicolumn{1}{|c|}{ Plants } & Mycelial growth* $(\mathbf{c m})$ & \% Inhibition \\
\hline P1 (Cabbage) & 0.00 & $100.00^{\mathrm{a}}(89.04)$ \\
\hline P2 (Cassava) & 0.00 & $100.00^{\mathrm{a}}(89.04)$ \\
\hline P3 (Garlic creeper) & 0.00 & $100.00^{\mathrm{a}}(89.04)$ \\
\hline P4 (Lemongrass) & 2.10 & $76.67^{\mathrm{d}}(61.59)$ \\
\hline P5 (Moringa) & 1.50 & $83.30^{\mathrm{c}}(66.18)$ \\
\hline P6 (Mustard) & 0.00 & $100.00^{\mathrm{a}}(89.04)$ \\
\hline P7 (Neem) & 2.00 & $77.80^{\mathrm{d}}(61.89)$ \\
\hline P8 (Papaya) & 6.50 & $27.78^{\mathrm{f}}(31.73)$ \\
\hline P9 (Radish) & 1.10 & $87.80^{\mathrm{b}}(69.56)$ \\
\hline P10 (Sweet potato) & 4.30 & $52.20^{\mathrm{e}}(46.28)$ \\
\hline Control & 9.00 & - \\
\hline SE m $( \pm)$ & - & 1.30 \\
\hline CD (0.05) & - & 2.14 \\
\hline
\end{tabular}

(Figures given in the parenthesis are transformed values).

*Mean of three replications.

Means followed by a common letter(s) are not significantly different by one- way ANOVA at $\mathrm{P}=0.05$ ) 
Table.3 Effect of soil biofumigation with selected plants under in vitro in confined containers on mycelial regeneration from sclerotia of $R$. solani

(\% suppression of mycelial regeneration from sclerotia)

\begin{tabular}{|c|c|c|c|c|}
\hline \multirow[t]{2}{*}{ Plants } & \multicolumn{4}{|c|}{ Mycelial regeneration from sclerotia of $\boldsymbol{R}$. solani } \\
\hline & After $24 \mathrm{~h}$ & After one week & $\begin{array}{l}\text { After two } \\
\text { weeks }\end{array}$ & $\begin{array}{l}\text { After one } \\
\text { month }\end{array}$ \\
\hline P1 & $\begin{array}{l}100.00^{\mathrm{a}} \\
(89.04)\end{array}$ & $\begin{array}{l}100.00^{\mathrm{a}} \\
(89.04)\end{array}$ & $\begin{array}{l}100.00^{\mathrm{a}} \\
(89.04)\end{array}$ & $\begin{array}{l}100.00^{a} \\
(89.04)\end{array}$ \\
\hline P2 & $\begin{array}{l}28.56^{b} \\
(36.47)\end{array}$ & $\begin{array}{l}61.48^{c} \\
(51.66)\end{array}$ & $\begin{array}{l}100.00^{\mathrm{a}} \\
(89.04)\end{array}$ & $\begin{array}{l}100.00^{a} \\
(89.04)\end{array}$ \\
\hline P3 & $\begin{array}{l}100.00^{\mathrm{a}} \\
(89.04)\end{array}$ & $\begin{array}{l}100.00^{\mathrm{a}} \\
(89.04)\end{array}$ & $\begin{array}{l}100.00^{\mathrm{a}} \\
(89.04)\end{array}$ & $\begin{array}{l}100.00^{\mathrm{a}} \\
(89.04)\end{array}$ \\
\hline P4 & $\begin{array}{c}44.11^{b} \\
(30.685)\end{array}$ & $\begin{array}{l}44.11^{e} \\
(41.60)\end{array}$ & $\begin{array}{l}77.40^{\text {de }} \\
(61.64)\end{array}$ & $\begin{array}{l}76.67^{d} \\
(61.13)\end{array}$ \\
\hline P5 & $\begin{array}{l}0.00^{\mathrm{d}} \\
(0.96)\end{array}$ & $\begin{array}{l}53.70^{d} \\
(47.12)\end{array}$ & $\begin{array}{l}77.04^{\mathrm{e}} \\
(61.37)\end{array}$ & $\begin{array}{l}81.11^{b} \\
(64.25)\end{array}$ \\
\hline P6 & $\begin{array}{l}100.00^{\mathrm{a}} \\
(89.04)\end{array}$ & $\begin{array}{l}100.00^{\mathrm{a}} \\
(89.04)\end{array}$ & $\begin{array}{l}100.00^{\mathrm{a}} \\
(89.04)\end{array}$ & $\begin{array}{l}100.00^{a} \\
(89.04)\end{array}$ \\
\hline P7 & $\begin{array}{l}12.78^{c} \\
(12.95)\end{array}$ & $\begin{array}{l}75.56^{b} \\
(60.39)\end{array}$ & $\begin{array}{l}80.00^{\mathrm{cd}} \\
(63.47)\end{array}$ & $\begin{array}{l}77.04^{d} \\
(61.40)\end{array}$ \\
\hline P8 & $\begin{array}{l}16.33^{c} \\
(15.44)\end{array}$ & $\begin{array}{l}55.56^{d} \\
(46.71)\end{array}$ & $\begin{array}{l}80.37^{c} \\
(63.74)\end{array}$ & $\begin{array}{l}79.63^{b c} \\
(63.18)\end{array}$ \\
\hline P9 & $\begin{array}{l}36.33^{b} \\
(36.72)\end{array}$ & $\begin{array}{l}42.59^{\mathrm{e}} \\
(40.73)\end{array}$ & $\begin{array}{l}77.41^{\text {de }} \\
(61.62)\end{array}$ & $\begin{array}{l}77.22^{\mathrm{cd}} \\
(61.62)\end{array}$ \\
\hline P10 & $\begin{array}{l}0.00^{d} \\
(0.96)\end{array}$ & $\begin{array}{c}44.44^{\mathrm{e}} \\
(40.730)\end{array}$ & $\begin{array}{l}84.80^{b} \\
(67.08)\end{array}$ & $\begin{array}{l}81.85^{b} \\
(64.79)\end{array}$ \\
\hline $\mathrm{C}$ & $\begin{array}{l}0.00^{\mathrm{d}} \\
(0.96)\end{array}$ & $\begin{array}{l}0.00^{\mathrm{d}} \\
(0.96)\end{array}$ & $\begin{array}{l}0.00^{\mathrm{d}} \\
(0.96)\end{array}$ & $\begin{array}{l}0.00^{\mathrm{d}} \\
(0.96)\end{array}$ \\
\hline $\begin{array}{c}\text { SE m } \\
(( \pm)\end{array}$ & 2.26 & 0.67 & 0.57 & 0.45 \\
\hline $\begin{array}{c}\text { CD } \\
(0.05)\end{array}$ & 3.02 & 2.44 & 2.07 & 1.64 \\
\hline
\end{tabular}

Means followed by a common letter(s) are not significantly different by one-way ANOVA at $\mathrm{P}=0.05$ ), Figures in the parenthesis are transformed values

P1 (cabbage), P2 (cassava), P3 (garlic creeper), P4 (lemon grass), P5 (moringa), P6 (mustard), P7 (neem), P8 (papaya), P9 (radish), P10 (sweet potato), C (Control) 


\section{Plate.1 a-c Bio-fumigation in confined condition}

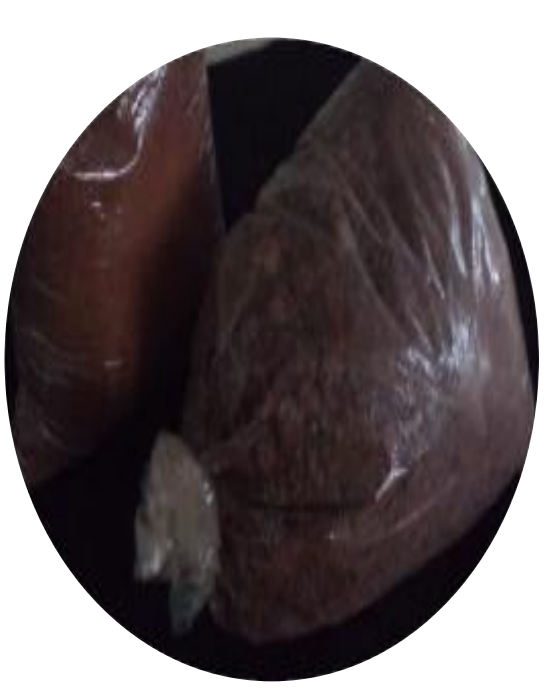

a. Sterilized soil

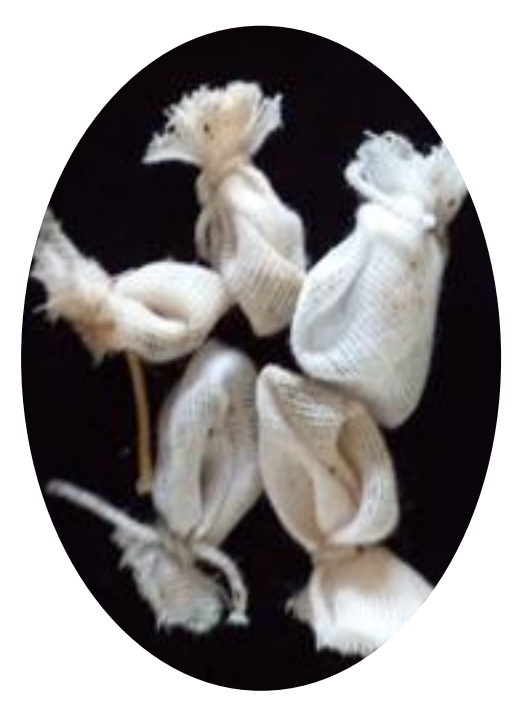

b. Muslin cloth bag carrying sclerotia

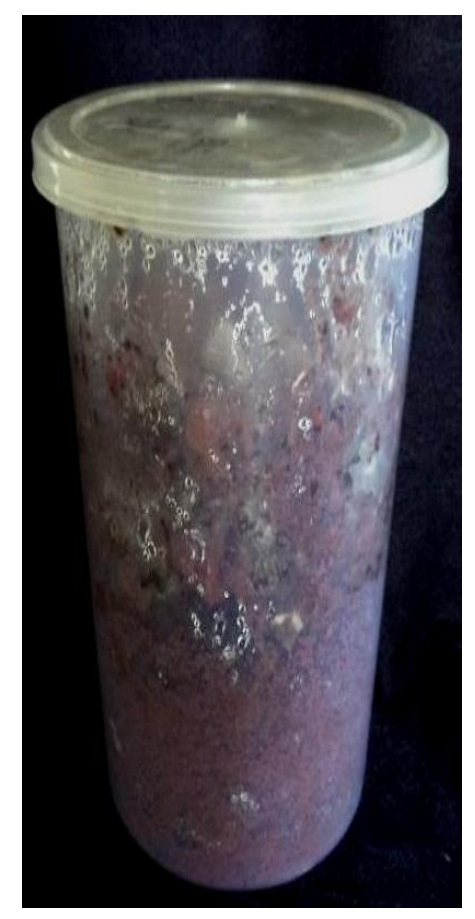

c. Confined container 
Plate.2 Bio-fumigant effect of plants against R.solani under in vitro conditions

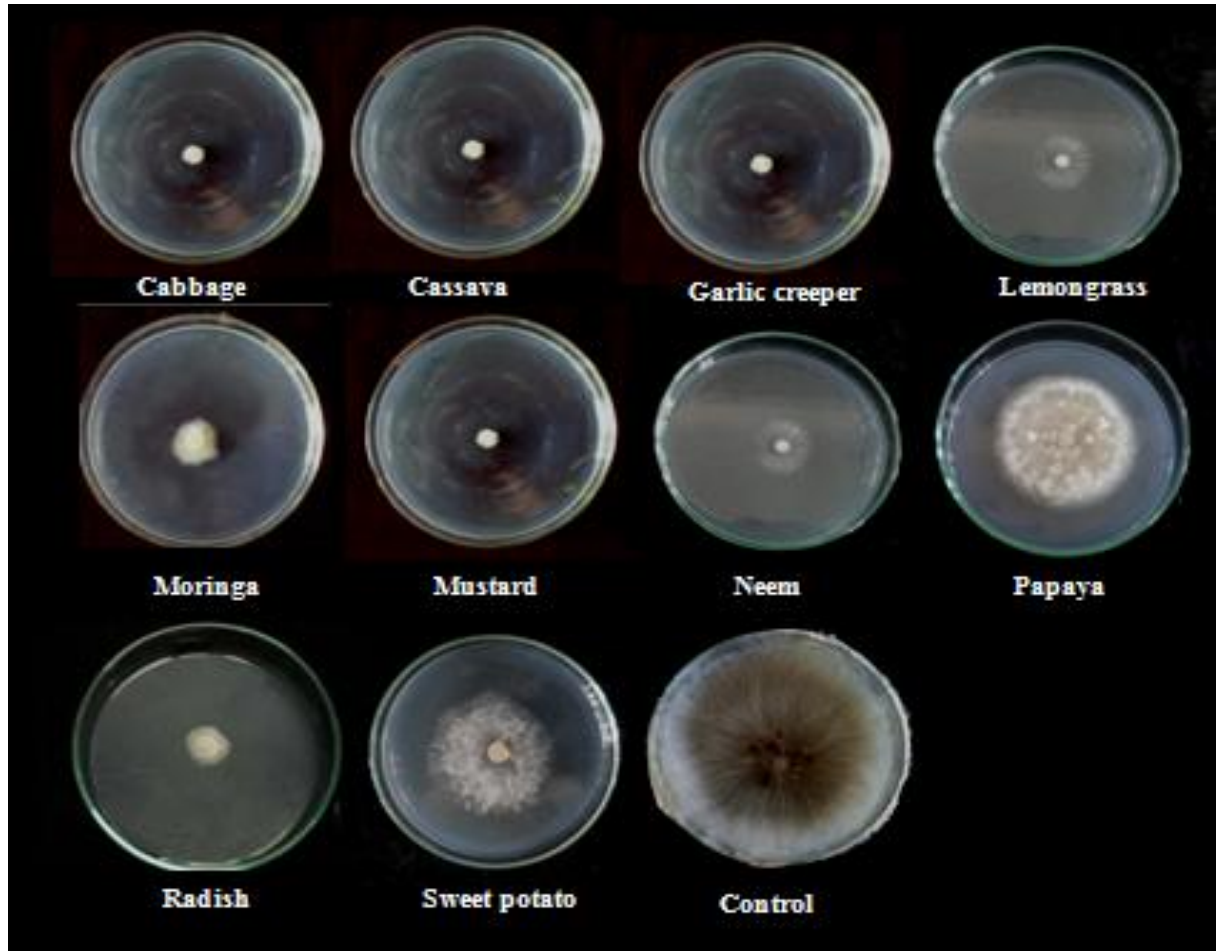

Plate.3 Effect of soil biofumigation with selected plants in confined containers on mycelial regeneration from sclerotia of $R$. solani (after 24h)

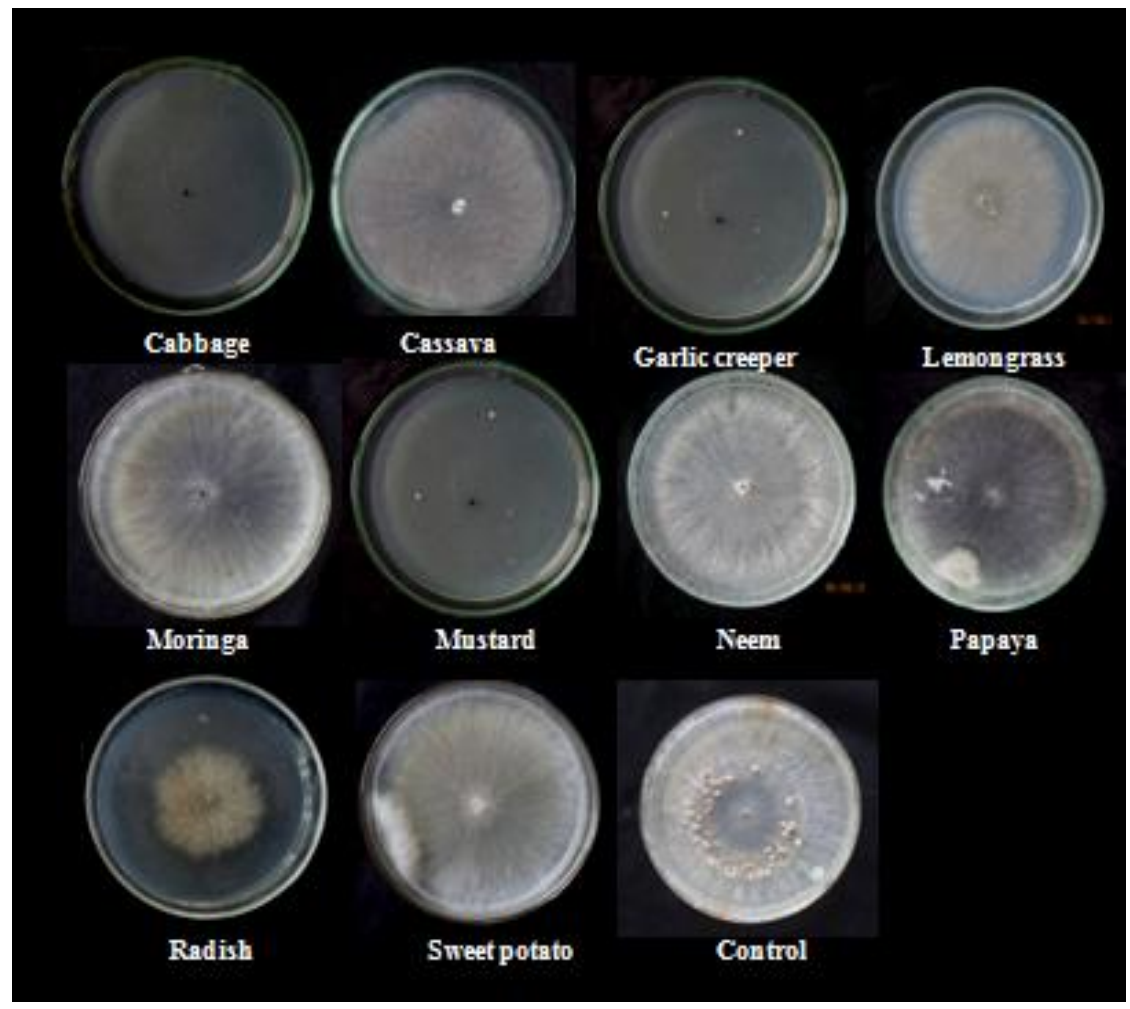




\section{Plate.4 Effect of soil biofumigation with selected plants in confined containers on mycelial} regeneration from sclerotia of $R$. solani (after one month)

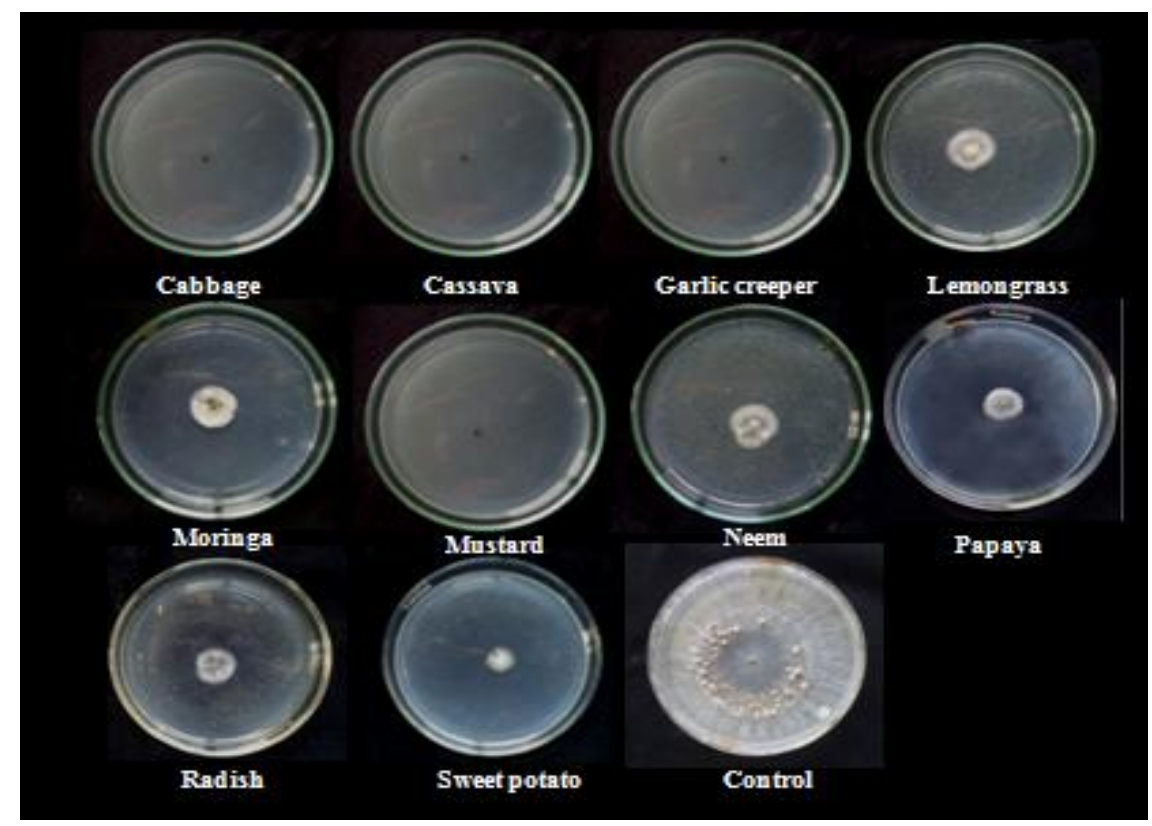

Among the plant extracts, cabbage and garlic creeper showed complete inhibition (100\%) and were significantly superior to all the other treatments. This was followed by extracts of wild mustard, radish and neem which gave an inhibition of $51.85 \%, 29.63 \%$ and $16.67 \%$, respectively. All the other plant extracts did not cause any suppression of the pathogen. Chandel and Sharma (2014) revealed that extracts of Melia azedarach and Adhatoda vasica showed maximum inhibition in mycelial growth of $R$. solani within the range of 44.38 to $44.25 \%$. They also reported that higher concentration of neem resulted in more inhibition of the $R$. solani and that more than $50 \%$ inhibition was recorded at a concentration of 40 per cent. Murugapriya et $a l$. , (2011) reported the complete inhibition of Macrophomina phaseolina with the extracts of Adenocalymma alliaceum and Allium spp. at concentration of $20 \%$. The in vitro biofumgant effect of the plants tested against R.solani showed significant differences between the treatments (Table 2). The maximum suppression (100\%) was noticed with cabbage, cassava, garlic creeper, mustard and wild mustard. This was followed by radish, moringa, neem and lemon grass which gave suppression of $87.88 \%, 83.33 \%$, $77.88 \%$ and $76.66 \%$, respectively. The suppression of pathogen in treatments with sweet potato and papaya recorded lower values of $52.2 \%$ and $27.78 \%$, respectively.

Charron and Sams (1999) reported that among the Brassica spp. the Indian mustard, Brassica juncea caused maximum inhibition of $R$. solani. Harvey et al., (2002) also supported that as a biofumigant, its property has been attributed to several allyl isothiocyanates present in it. Reddy (2012) suggested that plants in the mustard family, such as mustard, radish, turnip, cabbage and rapeseed, and members of Poaceae such as Sorghum species (Sudan grass, SorghumSudan grass hybrids) showed the potential to serve as biological fumigants. Chandel and Sharma (2014) noticed that cabbage was found most effective in reducing the incidence of stem rot in carnation. 
In order to assess the effect of biofumigation on survival of sclerotia in the soil, in vitro soil biofumigation study was carried out under confined conditions in sealed containers with plants. In general, biofumigation with plants exerted suppression of mycelial regeneration from sclerotia. The extent of suppression was found to increase with increase in period of incubation with biofumigants (Table 3). Among the plants, treatment with cabbage, garlic creeper and mustard were found to be very effective and caused 100 per cent suppression on mycelial regeneration from sclerotia $24 \mathrm{~h}$ after exposure to the treatment. Dubey et al., (2009) found inhibitory effect of neem extract on survival of sclerotia of $M$. phaseolina after 2 and 4 days of incubation. This was attributed to the presence of several bioactive compounds such as sulphur, neem, alkaloids, resins, glycosides, ammonia and fattyacids and ammonia evolved during the decomposition of neem oil and seed cake. Neem contains a variety of chemical constituents such as nimolicinol, isolimolicinolide, azadirachtin, azadirachtol, nimlinone, nimbocinol, nimbocinone, nimocin etc. (Tewari, 1992). Dubey and Kumar (2004) reported the antifungal effect of azadirachtin as effective as the fungicides: carbendazim and mancozeb. Biofumigation with plants belonging to Brassicaceae such as B. juncae and Raphanus sativus drastically reduced the viability from sclerotia of $S$. sclerotiorum (Warmington and Clarkson, 2016) and from microsclerotia of Verticillium dahliae (Neubauer et al., 2014). After a period of two weeks of biofumigation with cassava 100 per cent suppression on sclerotial growth was noticed. Biofumigation with leaves of other plants such as sweet potato, moringa, papaya, neem and lemongrass, which are widely grown in Kerala afforded suppression of 81.85, 81.11, 79.63, 77.04 and 76.67 per cent, respectively one month after exposure to the treatment. Though the suppression was significantly less as compared to the best treatments in this study, the availability and affordability make them promising candidates for further exploitation for biofumigation.

\section{References}

Agrios, G. N. 1997. Plant Pathology (4 ${ }^{\text {th }}$ Edn.). Academic press, New York, 606p.

Chandel, S. and Sharma, S. 2014. Botanicals, biofumigants, and antagonists application in managing stem rot disease caused by Rhizoctonia solani Kuhn in carnation. J. Biopest 7(1): 3-10.

Charron, C. S. and Sams, C. E. 1999. Inhibition of Pythium ultimum and Rhizoctonia solani by shredded leaves of Brassica species. J. Am. Soc. Hortic. Sci. 124: 462-467.

Dubey, N. K., Kumar, R. and Tripathi, P. 2004. Global promotion of herbal medicine: India's opportunity. Curr. Sci. 86(1): 37-41.

Dubey, R.C., Kumar, H., and Pandey, R. R. 2009. Fungitoxic effect of neem extracts on growth and sclerotial survival of Macrophomina phaseolina in vitro. $J$. Am. Sci.5: 17-24.

Kirkegaard, J. A., Gardner, P. A., Desmarchelier, J. M., and Angus, J. F. 1993. Biofumigation- using Brassica species to control pests and diseases in horticulture and agriculture. In: Wratten, M., Mailer, R. J. (eds), Proceedings of the Nineth Australian Research Assembly on Brassicas. Agricultural Research Institute, Wagga. pp.77- 82.

Kumar, S., Thripathi, H. S., and Singh, D. 2014. Evaluation of systemic and nonsystemic fungicides in vitro and in vivo condition against web blight disease of urd bean. J. Agrisearch 1(1): 45-48.

Matthiessen, J. N. and Kirkegaard, J. A. 2006. Biofumigation and enhanced 
biodegradation: opportunity and challenge in soilborne pest and disease management. Crit Rev. Plant Sci. 25(3): 235-265.

Mawar, R. and Lodha, S. 2002. Brassica amendments and summer irrigation for the control of Macrophomina phaseolina and Fusarium oxysporum $\mathrm{f}$ sp. cumini in hot arid region. Phytopathol. Mediterr. 41: 45-54.

Murugapriya, E., Alice, D., and Jayamani, P. 2011. Antifungal activity of botanicals and micro-nutrients against Macrophomina leaf blight in mung bean. J. Food Legumes 24(2): 113-116.

Nene, Y. L. and Thapliyal, P. N. 1993. Fungicides in Plant Disease Control ( ${ }^{\text {rd }}$ Ed.). Oxford and IBH Publishing Co. Pvt. Ltd. 691 p.

Neubauer, C., Heitmann, B., and Muller, C. 2014. Biofumigation potential of Brassicaceae cultivars to Verticillium dahliae. Eur. J. Plant Pathol. 140(2): 341-352.

Patel, M. D., Lal, A. A., and Singh, P. P. 2014. Efficacy of certain bio agent as and fungicides against root rot of chilli (capsicum annum L.). The Bioscan. 9(3): 1273-1277.

Paul, P. K. and Sharma, P. D. 2002. Azadirachta indica leaf extract induces resistance in barley against leaf stripe disease. Physiol. Mol. Plant Pathol. 61: 3-31.

Prasad, P., Kumar, J., and Pandey, S. 2016. Investigating disease controlling ability of Brassica volatiles and their compatibility with Trichoderma harzianum. Natl. Acad. Sci., India, Sect. B. Biol. Sci. The National Academy of Sciences, India doi: 10.1007/s40011016-0829-5.

Redovnikovic, I. R., Glivetic, T., Delonga, K. and Vorkapic-furac. J. 2008. Glucosinolates and their potential role in plant. Periodicum Biologorum 11(4): 297-309.

Sarwar, M., Kirkegaard, J. A., Wong, P. T., and Desmarchelier, J. M. 1998. Biofumigation potential of brassicas. iii in vitro toxicity of isothiocyanates to soil borne fungal pathogens. Plant and Soil 201(1):103-112.

Tewari, D. N. 1992. Monograph on neem (Azadirachta indica A. Juss.). International Book Distributors. 212p.

Tiwari, A. and Khare, M. N. 2002. Conditions inducing imperfect and perfect stages in Rhizoctonia solani causing diseases of mung bean. $J$. Mycol. Plant Pathol. 32: 176-180.

Upamanyu, S., Gupta, S.K., and Shyam, K.R. 2002. Innovative approaches for the management of root rot and web blight (Rhizoctonia solani) of French bean. J.Mycol.Plant Pathol. 32: 317-331.

Vincent, J.M. 1947. Distortion of fungal hyphae in the presence of certain inhibitors. Nature 150: 850.

Warmington, R and Clarkson J. P. 2016. Volatiles from biofumigant plants have a direct effect on carpogenic germination of sclerotia and mycelial growth of Sclerotinia sclerotiorum. Plant and Soil 401: 213-229.

\section{How to cite this article:}

Aparna, K.P. and Girija, V.K. 2018. Effect of Biofumigation with Plant Extracts on Mycelial Growth and Sclerotial Germination of Rhizoctonia solani Causing Collar Rot and Web Blight of Cowpea. Int.J.Curr.Microbiol.App.Sci. 7(03): 2990-2999.

doi: https://doi.org/10.20546/ijcmas.2018.703.346 